trials (Pretreatment by Trial Blocks interaction: $F=10.64 . \mathrm{dt}=$ $1.54 . \mathrm{p}<.01)$. The animals from the groups of 32. which were expected to exhibit helplessness-like behavior. showed initially high latencies which decreased dramatically as they belatedly. acquired the task (across trial blocks. nonpreshocked Group 32: $\mathrm{F}=21.65$. df $=1.9 . \mathrm{p}<.01$ ).

An indirect outcome of the present results is a further indication of the generality of the learned helplessness phenomenon described in dogs by Overmier \& Seligman (1967). and in albino rats by Maier et al (in press) and Looney \& Cohen (1972). Exposure to uncontrollable electric shock clearly depressed FR-2 shuttlebox performance in a different strain of rats over a wide range of housing conditions.

Both body and adrenal weight data accord with previous reports (e.g., Morrison \& Thatcher, 1969; Brain \& Nowell. 1970). These data and others indicate that overcrowding is a severe stress in various species, the effects of which can be manifest in behavior. Whether the decrement in initial FR-2 performance in the present study resulted from an interaction between this social stress and the stress of the training task. or whether it may represent some more complex effect of the crowded environment upon cognitive function, remains to be determined.

\section{REFERENCES}

Bell. R. W., Miller, C. E.. Ordy, J. M., \& Rolsten, C. Effects of population density and living space upon neuroanatomy, neurochemistry, and behavior in the C57B $1 / 10$ mouse. Journal of Comparative \& Physiological Psychology, 1971, 75, 258-263.

Brain, P. F., \& Nowell. N. W. Some endocrine and behavioral changes in the development of the albino laboratory mouse. Communications in Behavioral Biology, 1969, 4, 203-220.
Brain. P. F.. \& Nowell. N. W. The effects of differential grouping on endocrine function of mature male albino mice. Physiology \& Behavior. 1970, 5, 907-910.

Calhoun, J. B. Population density and social pathology. Scientific American, 1962, 206, 139-148.

Christian. J. J. Effects of population size on the adrenal glands and reproductive organs of male mice in populations of fixed size. American Journal of Physiology, 1955, 182, 292-300.

Galle. O. R.. Gove. W. R., \& McPherson, J. M. Population density and pathology: What are the relations for man? Science. 1972, 176. 23-30.

Goeckner, D. J.. Greenough, W. T., \& Mead. W. R. Deficits in learning tasks following chronic overcrowding in rats. Journal of Personality \& Social Psychology, 1973, 28, 256-261.

Looney, T. A.. \& Cohen. P. S. Retardation of jump-up escape responding in rats pretreated with different frequencies of noncontingent electric shock. Journal of Comparative \& Physiological Psychology, 1972, 78, 317-322.

Maier, S. F.. Albin, R. W., \& Testa, T. J. Failure to learn to escape in rats previously exposed to inescapable shock depends on the nature of the escape response. Journal of Comparative \& Physiological Psychology, in press.

Maier. S. F., Seligman, M. E. P., \& Solomon, R. L. Pavlovian fear conditioning and learned helplessness: Effects on escape and avoidance behavior of (a) the CS-US contingency and. (b) the independence of the $U S$ and voluntary responding. In $B$. A. Campbell and R. M. Church (Eds.), Punishment. New York: Appleton-Century-Crofts, 1969.

Morrison, B. J., \& Thatcher, K. Overpopulation effects on social reduction of emotionality in the albino rat. Journal of Comparative \& Physiological Psychology, 1969, 69, 658-662.

Overmier, J. B., \& Seligman, M. E. P. Effects of inescapable shock upon subsequent escape and avoidance responding. Journal of Comparative \& Physiological Psychology, 1967,63. 28-33.

Winer. B. J. Statistical principles in experimental design. New York: McGraw-Hill, 1962.

(Received for publication October 19, 1973.)

\title{
Changes in arousal as a function of emotional or nonemotional appraisal*
}

\author{
BRUCE C. WITTMAIER \\ Eisenhower College. Seneca Falls, A.Y. 13148
}

Eighteen college freshmen were given a list of "arousal" or "relaxation" side effects after taking a placebo pill. All were then aroused by experiencing failure on a test supposedly predictive of college success. It was predicted that Ss who made an emotional appraisal of the situation (those who could not attribute

*Sponsored by Ralph Norman Haker, who takes full editorial responsibility for its contents. their arousal to the pill) would evidence a higher level of arousal by outperforming Ss making a nonemotional appraisal (those who could attribute their arousal to the pill) on a simple learning task. The prediction was confirmed.

The cognitive theory of emotion (Schachter. 1971) suggests that an emotional response is a joint function of (1) the arousal state of the person. and (2) the particular cognitions the person associates with his aroused condition. Differing cognitions can give emotional or nonemotional meaning to the arousal. In an important 
paper, Schachter \& Singer (1962) demonstrated that arousal produced by an adrenalin injection was interpreted differentially when Ss expected drug-induced arousal than when they believed the arousal was a result of their involvement in an emotional situation. Those expecting drug-induced arousal were less emotional than those who assumed their arousal was a function of the situation.

A subsequent study by Nisbett \& Schachter (1966) further illustrated the arousal-cognition relationship. Ss, informed that they would experience autonomic arousal from a pill (actually a placebo) they had just taken, found a series of electrical shocks less intense than other Ss who could only interpret their emotional arousal as produced by the shocks they received. It would seem that those anticipating pill arousal found the shocks less arousing, had a less intense emotional response to them, and therefore evaluated them as less painful than those who assumed their arousal was shock produced. Similar misinterpretation of stimulus-produced arousal, and consequent reevaluation of the emotion-producing character of that stimulus, has been demonstrated by Ross, Rodin, and Zimbardo (1969), Storms \& Nisbett (1970), and Dienstbier \& Munter (1971).

Concepts developed from attribution theory (Kelley, 1967) have been used to identify the conditions leading to an emotional or a nonemotional appraisal of a stimulus. Nisbett \& Valins (1971) have discussed the importance of attributing one's arousal to the intrinsic qualities of a particular stimulus (to the shock in the Nisbett and Schachter study) or to factors extrinsic or circumstantial to that stimulus (to the pill). They conclude that "if the individual believes that his arousal is produced by the stimulus, he infers that he feels strongly about the stimulus and displays emotion toward it. If the individual believes that his arousal is produced by circumstances unrelated to the stimulus, he does not infer that he feels strongly about the stimulus, and is not likely to be emotional [p. 9]."

A number of investigators have examined the effect of attributing arousal to factors intrinsic or extrinsic to a stimulus (e.g., Ross, Rodin, \& Zimbardo, 1969; Storms \& Nisbett, 1970; Dienstbier \& Munter, 1971). All, however, have focused on the impact of an emotional or nonemotional appraisal on behavior directly related to the stimulus in question. None has attempted to assess whether or not there are more general effects produced as a function of the appraisal. This study was designed to examine possible general effects of appraisal; specifically, it was hoped to demonstrate an effect of appraisal on arousal.

It is clear, from Schachter \& Singer (1962), that arousal is necessary for an emotional appraisal of a stimulus to occur and that the arousal need not have been caused by that stimulus. What is not clear is whether the appraisal, when arousal is present, has an effect on that arousal, though it would seem that an emotional appraisal should raise arousal while a nonemotional appraisal should lower it.

While there is no unambiguous way of measuring arousal, there is substantial evidence that arousal affects task performance in predictable ways. Increasing arousal, for example, facilitates performance on simple tasks (Spence \& Spence, 1966). If appraisal has an effect on arousal, Ss making differing appraisals should also show task performance differences. As it was expected that an emotional appraisal would raise arousal and nonemotional appraisal would lower it, it was predicted that Ss making an emotional appraisal of a situation would perform more effectively on a simple task than would those who made a nonemotional appraisal. The relationship between arousal and performance on a difficult task is complex, so only a simple task was used.

\section{METHOD}

\section{Subjects}

Eighteen male freshmen at Eisenhower College volunteered for this study, the only inducement being an appeal from $E$. The students were contacted in an all-freshman course and were told that the study was to test the effects of a vitamin supplement on vision. None of the Ss had taken a course in psychology, and none had previously participated in a psychological experiment.

\section{Procedure}

A modification of the procedures of Dienstbier \& Munter (1971) was used. All Ss were run in one session and were randomly assigned to the two experimental conditions.

\section{Placebo Manipulations}

After being seated, the Ss were again told that the experiment dealt with the effect of a vitamin supplement on vision. Possible side effects of the drug were described as mild and harmless. After the Ss were given the opportunity to decline to participate (none did), the placebos were distributed. Each $\mathrm{S}$ also received a form describing the drug either as SUPROXIN, with such possible side effects as "a pounding heart, hand tremor, sweaty palms, a warm or flushed face, and a tight or sinking feeling in the stomach," or as SUPRAXIN, with side effects of "an increased tendency to yawn, a lessening of eye blink rate, and 'tired eyes.' " Thus, SUPROXIN was associated with symptoms typical of anxiety, while SUPRAXIN was described as having relaxation side effects.

\section{Arousal Task}

The Ss were then told that there would be a 10 -min wait before the drug's visual effect would be manifested. In the interim, they were to take a special vocabulary test the college was considering for use in screening students. The cover story indicated that this test was highly predictive of college success, but that it was necessary to develop local norms. Ss were asked to put their names and phone numbers on the tests because "we know that few successful college students score less than 20 on this test. In case you do, a faculty committee has been chosen to question you about your subnormal performance. Your performance on this test is particularly important in light of the impending visit by an accreditation agency" (Ss were aware of the visit). After completing the test, the Ss scored their papers. None scored higher than 18. Given students' customary responses to tests and poor performances, the task should have generated anxiety. This was established in pretesting.

\section{Salience Tasks}

After the vocabulary test, the $E$ described the visual perception task, reminding the Ss that this was the crucial phase of the study. The Ss then observed a pinpoint light source in the 
completely darkened room and indicated. by writing a code letter on a blank sheet of paper. how the light appeared to be moring at the end of a series of $30-\sec$ periods. All Ss perceived movement. and none was aware of the autokinetic effect.

The Ss were then told that it would be a few minutes before the next phase of the experiment, a self-rating of the drug side effects. After looking over the rating form (to make the side effects salient), the Ss were told that, to fill the time until the rating form could be completed. they would participate in a brief verbal learning task the $\mathrm{E}$ wanted to pretest.

A noncompeting associates list of 15 pairs was used (Spence et al. 1956). The words were presented with a slide projector on 3 screen at the front of the room as follows: $10 \mathrm{sec}$ per stimulus, $5 \mathrm{sec}$ per pair, and $5 \mathrm{sec}$ between trials. Ss recorded their responses. one per page, in a small booklet.

Following the learning task, the Ss completed the side effects checklist. an adjective checklist, and a postexperimental questionnaire assessing their impressions of the study, especially whether or not they thought the vocabulary test and learning task were related to the drug portion of the experiment. When all forms were completed, the Ss were completely debriefed.

\section{RESULTS AND DISCUSSION}

All Ss provided usable data. None indicated suspiciousness of a relationship between the pill portion of the study and the verbal learning task. As was predicted. Ss in the condition maximizing the likelihood of an emotional appraisal achieved higher scores on the simple learning task than did those in the condition where a nonemotional appraisal was likely [emotional appraisal (SUPRAXN): $\overline{\mathrm{X}}=9.78, \quad \mathrm{SD}=2.87$ nonemotional appraisal (SUPROXIN): $\overline{\mathrm{X}}=7.33 . \mathrm{SD}=$ 1.86. $t=2.14, \mathrm{p}<.05$, one-tailed test $]$.

Responses to the drug side effects questionaire did not show differences between the experimental groups. The adjective checklist was scored for the anxiety and fatigue factors (Nowlis \& Green, 1965) and the activation factor (Thayer, 1967), as these seemed most clearly related to the arousal concept. No differences were detected on any of these measures.

The data from the learning task support the hypothesis that making an emotional or nonemotional appraisal will have an impact on arousal. not just the interpretation of that arousal. It appears that the outcomes of the attribution process are more general than is suggested by previous studies, which demonstrated behavior changes only directly involving the potentially emotion-arousing stimulus. A variety of behaviors could be altered as a result of change in general arousal.

More attention must be given to establishing the extent of the influence of emotional and nonemotional appraisals. As in all previous experiments, the dependent measures in this study were taken rather soon after the attribution manipulation and were clearly within the experimental context. It would be especially useful to have some measures of emotional reactivity taken after the $\mathrm{S}$ leaves the laboratory. The behavioral and temporal limits of an appraisal must be established.

While attribution studies have consistently found behavioral differences between Ss making emotional and nonemotional appraisals. these studies have also been consistent in failing to obtain verbal report differences (Storms \& Nisbett, 1970: Dienstbier \& Munter. 1971). Perhaps the verbal report must be obtained much sooner after the attribution manipulation than has typically been the case. It may be that verbal reports are not sufficiently sensitive to the kinds of changes which occur as the result of differing appraisals.

Possible therapeutic applications of attribution have been extensively discussed (Davison \& Valins. 1969: Ross. Rodin. \& Zimbardo. 1969: Storms \& Nisbett. 1970: Valins \& Nisbett, 1971). The arousal manipulation in this study was similar to the naturally occurring condition called test anxiety. While the focus here was on obtaining arousal differences between the experimental groups, if an arousal reduction can be obtained by arranging conditions for a nonemotional appraisal, these Ss should then perform more effectively on a complex task such as a test. A procedure using a placebo attribution model followed by "dehoaxing" might be developed for use with test-anxious students. Davison \& Valins (1969) demonstrated that Ss benefited from finding that they. rather than a drug. were responsible for their behavioral improvement. The therapeutic potential of the attribution model deserves further study.

\section{REFERENCES}

Davison, G., \& Valins, S. Maintenance of self-attributed and drug-attributed behavior change. Journal of Personality \& Social Psychology, 1969, 11, 25-33.

Dienstbier, R., \& Munter, P. Cheating as a function of the labeling of natural arousal. Journal of Personality \& Social Psychology, 1971, 17, 208-213.

Kelley. H. Attribution theory in social psychology. In D. Levine (Ed.). Nebraska Symposium on .Iotication. Vol. 15. Lincoln: University of Nebraska Press, 1967. Pp. 192-240.

Nisbett, R., \& Schachter, S. Cognitive manipulation of pain. Journal of Experimental Social Psychology, 1966, 2, 227-236.

Nisbett. R.. \& Valins, S. Perceiving the causes of one's ou'n behailior. Morristown. New Jersey: General Learning Press, 1971 .

Nowlis, V., \& Green. R. Factor analytic studies of the mood adjective checklist. Technical Report Number 11. Office of Naval Research. Contract No. Nonr-668 (12), 1965.

Ross, L.. Rodin, J., \& Zimbardo. P. Toward an at tribution theory: The reduction of fear through induced cognitive-emotional misattribution. Journal of Personality \& Social Psychology, 1969, 12, 279-288.

Schachter, S. Emotion, obesity and crime. New York: Academic Press, 1971.

Schachter, S., \& Singer. J. Cognitive. social and physiological determinants of emotional state. Psychological Review, 1962. 69. 379-399.

Spence, K., Farber, I.. \& McFann. H. The relation of anxiety (drive) level to performance in competitional and noncompetitional paired-associates learning. Journal of Experimental Psychology. 1956.52. 296-305.

Spence. K., \& Spence. J. Hotivational components of manifest anxiety: Drive and drive stimuli. In C. Spielburger (Ed.), Anxiety and behatior. New York: Academic Press, 1966.

Storms, M.. \& Nisbett. R. Insomnia and the attribution process. Journal of Personality \& Social Psychology. 1970. 16, 319-328.

Thayer, R. Measurement of activation through self-report. Psychological Reports, 1967. 20. 659-662.

Valins. S. \& Nisbett, R. Attribution processes in the development and treatment of emotional disorder. Morristown. New Jersey: General Learning Corporation. 1971.

(Received for publication October 6. 1973.) 